UDC 614.712:614.715

O.G. Butenko, $\mathrm{PhD}$, Assoc.Prof.,

S.Yu. Smyk, PhD

Odessa National Polytechnic University, 1 Shevchenko Ave., 65044 Odessa, Ukraine; e-mail: alex_butenko@ukr.net

\title{
ASSESSMENT OF CLEANING EFFICIENCY OF THE POLYDISPERSE GAS FLOW IN DOUBLE-FLOW DEDUSTING SYSTEM
}

\begin{abstract}
О.Г. Бутенко, С.Ю. Смик. Оцінка ефективності очищення полідисперсного газового потоку у двопотоковій системі знепилення. Одним з пріоритетних завдань природоохоронної діяльності на промислових підприємствах $є$ підвищення якості очищення газових викидів від полідисперсного пилу. Для розв'язання проблеми уловлення дрібно-фракційного пилу запропоновано двопотокову систему очищення. Мета: Метою роботи є визначення виду залежності ефективності очищення полідисперсного газового потоку від коефіцієнта розділення газу у двопотоковій системі очищення. Матеріали $\boldsymbol{i}$ методи: Проведено аналіз впливу коефіцієнта розділення газу у розділяючому апараті двопотокової системи очищення на її ефективність. Шляхом складання матеріального балансу системи за газом і за масою пилу отримано загальну залежність для проскоку основного уловлювача, яка характеризує загальну ефективність системи. Результати: Показано, що значення коефіцієнта проскоку основного уловлювача залежить від безрозмірних показників ефективності обладнання. Отримана загальна залежність коефіцієнта проскоку від коефіцієнта розділення дозволяє визначити оптимальне значення коефіцієнта розділення для будь-якої знепилюючої комбінованої системи.

Ключові слова: коефіцієнт розділення, двопотокова система очищення, коефіцієнт проскоку.

O.G. Butenko, S.Yu. Smyk. Assessment of cleaning efficiency of the polydisperse gas flow in double-flow dedusting system. One of priority problems of nature protection activity at the industrial enterprises is upgrading the gas emissions cleaning of polydispersed dust. To solve the problem of catching of small fraction dust the double-flow dedusting system has been offered. Aim: The aim of the work is to determine the dependency type of the cleaning efficiency of polydisperse gas flow on gas separation factor double-flow dedusting system. Materials and methods: The analysis of influence of gas separation factor in the dividing device of double-flow dedusting system on its efficiency is carried out. By drawing up the mass balance of system on gas and on the mass of dust the general dependence for breakthrough of the main catcher, characterizing overall effectiveness of system, is received. Results: It is shown that value of breakthrough factor of the main catcher depends on dimensionless efficiency factors of the equipment. The received general dependence of breakthrough factor on separation factor allows to define the optimum value of separation factor for any combined dedusting system.

Keywords: separation factor, double-flow dedusting system, breakthrough factor.
\end{abstract}

Introduction. One of priority problems of nature protection activity at the industrial enterprises is upgrading the gas emissions cleaning of polydispersed dust. Large enterprises, for example, thermal power plants or iron and steel plants, implement modern and expensive clearing devices in production for this purpose. Small enterprises, generally for economic reasons, are not able to carry out such modernization. Therefore, the development of rather simple and inexpensive system which would provide considerable improvement of gas stream cleaning of polydisperse dust is important and actual problem.

The analysis of current state of dedusting technologies shows that in the most ecologically dangerous industry - thermal power - mainly direct-flow systems are used with some one type of the dust arrester (battery cyclone, wet scrubber or the electric precipitator). Hybrid systems of dust cleaner for power industry are only at development stage [1]. In metallurgy, as Stalinskiy and Shvets note $[2,3]$, more complex systems are used and, nevertheless, they also are direct-flow ones. In addition to the filters called above, cloth filters are often used there and at certain stages of cleaning gravitational installations [4]. The main problem of the most widespread dust collectors is low efficiency of purification from small-fractional components of dust. Therefore, it is natural that the most modern researches in this sphere are directed to improvement of this aspect of equipment work. So, Peukert W. and Wadenpohl C. [5] consider question of extraction of dust particles with extreme properties from the lump, in particular with extremely small sizes. It is shown that the mechanism of

DOI 10.15276/opu.1.48.2016.09

(C) 2016 The Authors. This is an open access article under the CC BY license (http://creativecommons.org/licenses/by/4.0/).

ENERGETICS. HEAT ENGINEERING. ELECTRICAL ENGINEERING 
separation process of dust particles by the size opens perspectives of the innovation methods development for cleaning the flow of dust nanoparticles. Dong Zhou [6] suggests to carry out acoustic coagulation of small-fractional raise dust before catching. The frequencies ranges of high intensity sound waves are received in the work and they provide the best results. The main lack of such method is need of the additional accessories use - the acoustic waves generator.

To solve the problem of small-fractional dust catching the authors offered double-flow dedusting system (DFDS) in works [7, 8]. Implementation of the scheme does not demand considerable capital investments, but provides considerable improvement of gas cleaning because of separate cleaning.

The technique of DFDS design offered earlier allows calculating its constructive and production characteristics, but does not provide the determination of flow separation factor value, that is optimum from the point of view of cleaning efficiency. The value of this factor was chosen from the recommended and rather wide interval. Dependence determination of cleaning efficiency on separation factor will allow to design the DFDS with the greatest possible efficiency for specific conditions.

The aim of the work is to determine the dependency type of the cleaning efficiency of polydisperse gas flow on gas separation factor double-flow dedusting system.

Materials and Methods. The double-flow scheme of dedusting is implemented in DFDS at the expense of dust division with fractional characteristic. The feature of such scheme is that dusty gas divides in the division device 2 before cleaning (Fig. 1). The flow containing small fractions with volume flow of $Q_{2-3}$ and concentration of $C_{2-3}$ arrives to the main catcher 3. As efficiency of catching of large and fractional dust is high for any traps, the dust breakthrough to the atmosphere $M_{\mathrm{br}}$ is minimum. This provides the ecological effect. The flow with thin fractions of volume flow of $Q_{2-4}$ and concentration of $C_{2-4}$ comes to traps of circulation loop 4. Its efficiency is low and therefore this flow with the high content of dust comes to the mixing device 1 . The modified central ejector [9] is used for this. There the flow mixes up with primary flow (flow from source), and further - through divider gets on cleaning again. Thus, cleaning from small-fractional dust performed due to repeated passing of flow the trap of circulation loop.

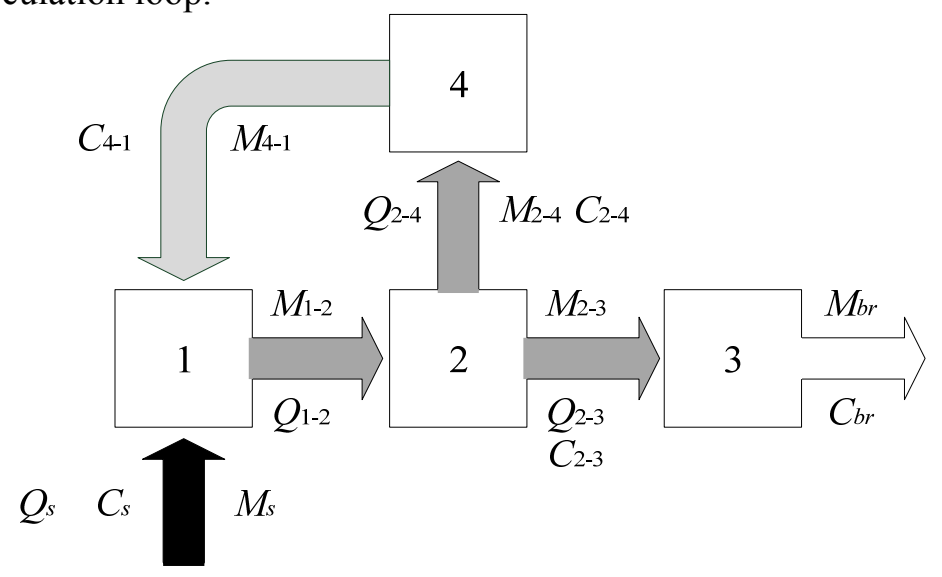

Fig. 1. Schematic diagram of double-flow cleaning system

At design of DFDS such characteristics are set: the volume flow coming to system from source $Q_{\mathrm{s}}$, the corresponding concentration of dust $C_{\mathrm{s}}$ and its disperse composition which is characterized by differential curve of distribution $N_{\mathrm{s}}=f(\Delta)\left(N_{\mathrm{s}}\right.$ - percentage of particles of the $D$ size in all dust mass $[10,11])$. Using these data it is necessary to choose the pressure and clearing equipment and also to calculate the design of the division device and its operational indicators [7,8]. At the same time the main characteristic which influences this calculation is separating ability on carrier gas

$$
q_{\mathrm{o}}=\frac{Q_{2-3}}{Q_{1-2}}=\frac{Q_{2-3}}{Q_{2-4}+Q_{2-3}}, \quad \text { or } \quad \frac{1}{q_{\mathrm{o}}}=1+\frac{Q_{2-4}}{Q_{2-3}},
$$


which, as a rule, is in range $0.04 \ldots 0.2$ [12]. The method of DFDS calculation developed earlier provides the choice of coefficient of $q_{\mathrm{o}}$ from the given interval without possibility of its optimum value determination. To eliminate this shortcoming, we will establish dependence of cleaning efficiency of DFDS on $q_{\mathrm{o}}$.

To assess the efficiency of DFDS we will make its mass balances on carrier gas and dust mass.

The balance on carrier gas is obvious: $Q_{1-2}=Q_{\mathrm{s}}+Q_{2-4}$ and $Q_{2-3}=Q_{\mathrm{s}}$.

Let set $k_{\mathrm{o}}$ as a dust quantity, that comes from divider to main catch mechanism, in this way

$$
k_{\mathrm{o}}=\frac{M_{2-3}}{M_{1-2}}=\frac{Q_{2-3} C_{2-3}}{Q_{1-2} C_{1-2}},
$$

where $M_{2-3}$ i $M_{1-2}$ - per-second dust masses, that come from divider to main catch mechanism from and from mixing device to divider device accordingly;

$C_{2-3}$ i $C_{1-2}-$ dust concentration at corresponding flows.

Then the flow balance for the dust mass:

- for the mixing device:

$$
\begin{gathered}
Q_{\mathrm{s}} C_{s}+Q_{2-4} C_{4-1}=Q_{1-2} C_{1-2}, \\
Q_{\mathrm{s}} C_{s}+Q_{2-4} C_{1-2}\left(1-k_{\mathrm{o}}\right)\left(1-\eta_{l}\right)=Q_{1-2} C_{1-2} ;
\end{gathered}
$$

— for the divider device

$$
\begin{gathered}
Q_{1-2} C_{1-2}=Q_{2-4} C_{2-4}+Q_{2-3} C_{2-3}, \\
Q_{1-2} C_{1-2}=Q_{l} C_{1-2}\left(1-k_{\mathrm{o}}\right)+Q_{2-3} C_{1-2} k_{\mathrm{o}} ;
\end{gathered}
$$

— for the main catch mechanism

$$
\begin{gathered}
Q_{2-3} C_{2-3}=\mathrm{M}_{\mathrm{br}}+M_{c}, \\
Q_{2-3} C_{2-3}=Q_{2-3} C_{1-2} k_{\mathrm{o}}\left(1-\eta_{\mathrm{o}}\right)+M_{c}=Q_{2-3} C_{b r}+M_{c},
\end{gathered}
$$

where $\eta_{\mathrm{o}}$ and $\eta_{l}$ - the efficiency coefficients of main and loop catch mechanisms, depending on its construction and distribution of dust particles, that comes to them;

$C_{b r}$ - dust concentration of breakthrough;

$M_{\mathrm{c}}$ - dust mass, caught in the main catch mechanism.

The common efficiency of DFDS is characterized by breakthrough factor $\varepsilon$, that is the ratio of dust mass, coming out from system to atmosphere, to dust mass, coming to system from the source. Whereas $Q_{2-3}=Q_{b r}$, then

$$
\varepsilon=\frac{C_{b r}}{C_{s}} .
$$

Using (1) and (2) well obtain

$$
C_{1-2}=\frac{C_{s}}{\frac{1}{q_{\mathrm{o}}}-\left(1-k_{\mathrm{o}}\right)\left(1-\eta_{l}\right)\left(\frac{1}{q_{\mathrm{o}}}-1\right)} .
$$

Then the dust concentration in flow, coming out to atmosphere, is calculated using formula

$$
C_{b r}=C_{1-2} k_{\mathrm{o}}\left(1-\eta_{\mathrm{o}}\right)=\frac{C_{s} k_{\mathrm{o}}\left(1-\eta_{\mathrm{o}}\right)}{\frac{1}{q_{\mathrm{o}}}-\left(1-k_{\mathrm{o}}\right)\left(1-\eta_{l}\right)\left(\frac{1}{q_{\mathrm{o}}}-1\right)},
$$

and the common breakthrough factor of a system is calculated using 


$$
\varepsilon=\frac{k_{\mathrm{o}}\left(1-\eta_{\mathrm{o}}\right)}{\frac{1}{q_{\mathrm{o}}}-\left(1-k_{\mathrm{o}}\right)\left(1-\eta_{l}\right)\left(\frac{1}{q_{\mathrm{o}}}-1\right)} .
$$

Let analyze the obtained dependency. When it is borderline case $q_{\mathrm{o}}=1$ then gas with dust is not flowed to circulating loop and $\varepsilon=k_{\mathrm{o}}\left(1-\eta_{\mathrm{o}}\right)$. As far as having $q_{\mathrm{o}}=1$ the dust quantity in main catch mechanism $k_{\mathrm{o}}=1$, then breakthrough factor of a system is $\varepsilon=\left(1-\eta_{\mathrm{o}}\right)$, that corresponds the case of classic straight-through arrangement $[10,11]$. In another borderline case when $q_{\mathrm{o}} \rightarrow 0$, then $k_{\mathrm{o}}=0$, it is uncertainty appears. That is physically means, that system cannot function at these conditions.

Results and Discussions. It is possible to argue on expediency of double-flow dedusting system use on the basis of comparison of results of its work with work of usual direct-flow system which uses one inertial trap. Replacement of direct-flow system by DFDS in crushing room of construction materials - the remains of dismantle of old buildings is made [7]. The catch factor of a cyclone direct-flow system have been operating before modernization is equal to 0.755 . In the constructed system with feedback the catching factor of the main device made 0.96 . Thus, emissions of dust with aspiration air to the atmosphere decreased approximately six times. The dividing ability on gas carrier in the implemented DFDS were set to 0.048. Calculations using formula (3) for data of this engineering task allowed to draw a conclusion that it is possible to reach even more high-quality purification of aspiration air due to decrease in this indicator to value 0.04 .

The received dependence (3) allows to draw several conclusions. Firstly, the breakthrough factor depends on initial concentration $C_{\mathrm{s}}$ and volume flow (volume expenses) $Q_{\mathrm{s}}$ only in that measure in which the separation factor of $k_{\mathrm{o}}$ and effectiveness ratio of cleaning depend on them $\eta_{\mathrm{o}}$ and $\eta_{l}$ in main and circulating traps respectively. Secondly, in borderline case the DFDS can theoretically work as usual direct-flow system.

The problem of optimum $q_{\mathrm{o}}$ value determination for double-flow system has no common solution as there is implicit dependence of $k_{\mathrm{o}}=f\left(q_{\mathrm{o}}\right)$ which is defined not only by design parameters of divider, but also by disperse composition of dust.

As well as, $\eta_{\mathrm{o}}=f\left(N_{2-3}\right)$ and $\eta_{l}=f\left(N_{2-4}\right)$, and mass of dust distribution on fractions in the divider device $N_{2-3}=f\left(q_{\mathrm{o}}\right)$ and $N_{2-4}=f\left(q_{\mathrm{o}}\right)$. In turn, these functions also depend on initial disperse composition $N_{\mathrm{s}}=f(\Delta)$, that is unique for each task. Thus, the search problem of resolution threshold optimal value of DFDS can be solved with help of (3) only for conditions of specific task after laboratory determination of $N_{\mathrm{s}}=f(\Delta)$.

\section{Література}

1. Miller, B.G. Advanced flue gas dedusting systems and filters for ash and particulate emissions control in power plants / B.G. Miller // Advanced Power Plant Materials, Design and Technology / ed. by D. Roddy. - Cambridge: Woodhead Publishing, 2010. — PP. 217 - 243.

2. Сталинский, Д.В. Анализ современных технических решений систем улавливания и очистки технологических газов и неорганизованных выбросов крупнотоннажных электросталеплавильных печей / Д.В. Сталинский, М.Н. Швец // Экология и промышленность. — 2010. — № 3. С. $4-9$.

3. Сталинский, Д.В. Инновационные решения УкрГНТЦ «Энергосталь» по очистке пылегазовыделений на промышленных предприятиях / Д.В. Сталинский, М.Н. Швец // Экология и промышленность. - 2011. - № 2. - С. $36-45$.

4. Geometry optimisation of a gravity dust-catcher using computational fluid dynamics simulation / D. Winfield, M. Cross, N. Croft, D. Paddison // Chemical Engineering and Processing: Process Intensification. - 2012. - Vol. 62. - PP. $137-144$.

5. Peukert, W. Industrial separation of fine particles with difficult dust properties / W. Peukert, C. Wadenpohl // Powder Technology. — 2001. - Vol. 118, Issues 1-2. - PP. 136 - 148. DOI:10.1016/S0032-5910(01)00304-7 
6. Experimental study on improving the efficiency of dust removers by using acoustic agglomeration as pretreatment / D. Zhou, Z. Luo, J. Jiang, et al. // Powder Technology. — 2016. — Vol. 289. — PP. 52 — 59.

7. Бутенко, А.Г. Комбинированная система очистки воздуха / А.Г. Бутенко, С.Ю. Смык // Энерготехнологии и ресурсосбережение. - 2010. - № 6. - С. $66-69$.

8. Бутенко, О.Г. Гідравлічний розрахунок комбінованої системи очищення повітря / О.Г. Бутенко, С.Ю. Смик // Пр. Одес. політехн. ун-ту. - 2011. - Вип. 1(35). — С. 191 - 195.

9. Бутенко, О.Г. Підвищення коефіцієнта корисної дії центрального ежектора за неоптимальних режимів роботи / О.Г. Бутенко, С.Ю. Смик // Науковий вісник НГУ. — 2015. — № 2. — С. 57 - 61.

10. Справочник по пыле- и золоулавливанию / М.И. Биргер [и др.]; общ. ред. А.А. Русанов. — 2-е изд., перераб. и доп. - М.: Энергоатомиздат, 1983. - 312 с.

11. Жабо, В.В. Охрана окружающей среды на ТЭС и АЭС / В.В. Жабо. - М.: Энергоатомиздат, 1992. - $240 \mathrm{c}$.

12. Бутенко, А.Г. Разделение твердой фазы полидисперсного потока по фракциям в комбинированной системе очистки / А.Г. Бутенко, С.Ю. Смык, Д.А. Мовила // Экология и промышленность. 2009. 一 № 4. - С. $74-76$.

\section{References}

1. Miller, B.G. (2010). Advanced flue gas dedusting systems and filters for ash and particulate emissions control in power plants. In D. Roddy (Ed.), Advanced Power Plant Materials, Design and Technology (pp. 217 - 243). Cambridge: Woodhead Publishing. DOI:10.1533/9781845699468.2.217

2. Stalinsky, D.V., \& Shvets, M.N. (2010). Analysis of present-day technical solutions on recovery and purification systems for process gases and non-organized emissions from large-tonnage electric steelmelting furnaces. Ecology and Industry, 3, $4-9$.

3. Stalinsky, D.V., \& Shvets, M.N. (2011). Innovative approaches of UkrSSEC “Energostal" in the sphere of powder-gas emission cleaning at industrial enterprises. Ecology and Industry, 2, 36 - 45.

4. Winfield, D., Cross, M., Croft, N., \& Paddison, D. (2012). Geometry optimisation of a gravity dustcatcher using computational fluid dynamics simulation. Chemical Engineering and Processing: Process Intensification, 62, 137 - 144. DOI:10.1016/j.cep.2012.08.001

5. Peukert, W., \& Wadenpohl, C. (2001). Industrial separation of fine particles with difficult dust properties. Powder Technology, 118(1-2), 136 - 148. DOI:10.1016/S0032-5910(01)00304-7

6. Zhou, D., Luo, Z., Jiang, J., Chen, H., Lu, M., \& Fang, M. (2016). Experimental study on improving the efficiency of dust removers by using acoustic agglomeration as pretreatment. Powder Technology, 289, 52 - 59. DOI:10.1016/j.powtec.2015.11.009

7. Butenko, A.G., \& Smyk, S.Yu. (2010). The combined air-cleaning system. Energy Technologies \& Resource Saving, 6, $66-69$.

8. Butenko, O.G., \& Smyk, S.Yu. (2011). Hydraulic calculation of the combined system of air cleaning. Odes 'kyi Politechnichnyi Universytet. Pratsi, 1, 191 - 195.

9. Butenko, A.H., Smyk, S.Yu. (2015). Improvement of the central ejector efficiency under nonoptimal operating modes. Scientific Bulletin of National Mining University, 2, $57-61$.

10. Rusanov, A.A. (Ed.). (1983). Handbook of Dust- and Ash-Collection. Moscow: Energoatomizdat.

11. Zhabo, V.V. (1992). Environmental Protection at TPPs and NPPs. Moscow: Energoatomizdat.

12. Butenko, A.G., Smyk, S.Yu., \& Movila, D.A. (2009). Division of solid phase of polydisperse stream into fractions in the combined cleaning system. Ecology and Industry, 4, 74-76. 